\title{
The Religion and Science Advocates in the Academic Debate
}

Unsurprisingly, the academic religion and science debate involves advocates of religion and science-theologians and scientists. In this chapter, I show that almost the entire debate involving scientists and theologians assumes that what is under debate is systemic knowledge. That is, to examine one strand, the debate is whether religion and science have always been locked in "warfare" over how to make claims about the natural world. Scientists point to Galileo's persecution by the Catholic Church for arguing that the Earth is not the center of the universe. On the other side, theologians work to resolve any conflict by making sure that there is no disagreement between the fact claims of science and that of religion. I will also explain why science and technology focus on a systemic knowledge relationship, and not on a moral relationship. Finally, I will, when possible, show that these elites assume that the public has the same relationship between religion and science as they do. They are never explicit about this. When it is not possible to determine if they are extrapolating their views to the public, the elite views remain important for us to consider because they are trying to teach the public a particular relationship between religion and science.

The scientists and the theologians create two problems for a healthy debate about religion and science in the public sphere. First, by writing as if all conflict is about knowledge, the public who consumes this material is taught that religion and science are in knowledge conflict and not moral conflict. Second, by not acknowledging that the concern with coherent knowledge is an elite activity, these writers imply that the public has systemic knowledge concerns, when in actuality the religious public may only be in propositional belief conflict with science. 
Before I get to the specific reasons that members of these two groups would view themselves as engaged in a systemic knowledge relationship, let me address two general explanations. First, to reiterate what I wrote in the Introduction, these two groups comprise academics and/or have a large amount of academic training, and are rewarded for thinking extensively on this exact topic. Therefore, all else being equal, they will have worked out systemic knowledge because, to oversimplify, that is what academia trains people to do.

Second, that academics would see the specific institutions of religion and science as both systemic knowledge systems is over-determined, and indeed has its origins before the sixteenth century Reformation. From the Greeks forward, religion, and science for that matter, were virtues of the individual. Historian Peter Harrison describes an early Christian author as seeing religion as "not a system of beliefs and practices but of godliness, modes of worship, a new kind of race, and a way of life." By the time of the Reformation, the meaning of "religion" begins to shift. The "interior virtues of scientia and religio" change. While catechisms had once been understood as techniques for developing an interior piety, they now came to be the essence of some objective thing-religion. In Harrison's words, "religion was vested in creeds rather than in the hearts of the faithful." That is, "religion" shifts from an "interior disposition" to "beliefs themselves." Protestant reformers further contributed to this idea by insisting that Christians be able to articulate the doctrines, and do so in propositional terms. The printing press also contributed to this process, as Protestant clergy stressed the importance of the inculcation of religious doctrines-now available more broadly. Indeed, catechisms came to embody the content of the Christian religion. ${ }^{1}$

Now conceptualized as a system of beliefs, religion could be "true" or "false." With this new idea of religion as a system of belief comes the idea that religion can be rationally justified. Harrison almost perfectly depicts my pyramid metaphor when he writes that for idealists, "the perfect religion would be a body of propositions, firmly established by ironclad logical demonstrations." At this point, he continues, "belief could be described as the act of giving intellectual assent to propositions.”

Ironically from the contemporary perspective, the "sciences" of the seventeenth century-called natural history and natural philosophy-were given the task of providing some of the general warrants to justify the new propositional religion, which reinforces the idea that religion should be understood as "a system of beliefs" that requires rational support. With this definition, religion was now capable of conflict with science because, in Harrison's words, "religion consists of factual claims that should be subject to scientific confirmation." The end result is that religion is "characterized by propositional beliefs, which, on par with beliefs in other spheres, require rational justification." 
There is general truth in the common wisdom that Protestantism is concerned with proper belief and Catholicism is concerned with proper practice, so this is a particularly Protestant way of looking at religion. But, it was Protestants who were at the center of these changes, and it was Protestantism that dominated the public square, academia, and public life in the U.S. until the mid-twentieth century. This idea of religion as a hierarchically justified system of belief and facts became the elite conception of what "religion" was, and thus influenced debate from that point forward.

So, any academic should be prone to seeing both religion and science as systemic knowledge. I will argue in later chapters that the "religion" described by Harrison as emerging before the Reformation and continuing to today either was never held by the ordinary members of these religions, or has run its course and is being changed into something else, at least in the U.S. For the remainder of the chapter I will examine how academic scientists and theologians view their own beliefs and the relationship to the beliefs of the other institution. Besides their own self-image of producing systemic knowledge, I will also explain why they see themselves in systemic knowledge conflict with the other, and why the possibility of moral conflict never seems to be discussed.

\section{CONTEMPORARY SCIENTISTS IN THE DEBATE: WE ONLY PRODUCE KNOWLEDGE}

Obviously one important set of elites in any debate between religion and science are contemporary scientists. They generally believe that any conflict with science by the public, religious or otherwise, is about a lack of knowledge by the public. For there to be a "religion and science" debate there must be scientists, but having them in a debate means accepting their premise that any conflict with them is only about knowledge.

The field of science communication offers us some studies of academic scientists in general, which offer background for my later examples of scientists in the religion and science debate itself. These studies do evaluate what these scientists think the public's views are, and reveal that scientists think that any conflict between them and the public-religious or otherwise-is about knowledge of the natural world. One study concludes that "almost universally" scientists "believe the public is inadequately informed about science topics." Further, scientists believe that, "the public is uninterested in becoming more knowledgeable," and that scientific illiteracy is at the root of opposition to new technologies and adequate science funding. The authors also summarize several studies that find that "scientists view the public as non-rational and unsystematic in their thinking such that they rely on anecdotes." That is, the public is accused of not using a system of knowledge. Other studies have found that scientists see the public as emotional, fear prone, focused on the sensational, self-interested, and "stubborn in the face of new evidence."4 
Similarly, a survey of members of the American Academy for the Advancement of Science found that 85 percent thought that "the public does not know very much about science" and this was a "major" problem "for science in general." When scientists were asked about public engagement, studies suggest that scientists view engagement as chiefly about information dissemination rather than dialogue. Moreover, "the primary argument that scientists give for public engagement is the need to increase citizen knowledge ... or allay unfounded fears," with engagement usually "framed in terms of providing information." That is, communication with the public, religious or otherwise, is about knowledge. Anticipating my later point that conflict may actually be about morality, these studies show that the key difficulty for scientists in public engagement "may be that scientists often believe public debates should turn on logic and cost-benefit-analysis accounting whereas the public wants consideration of factors such as fairness, ethics, and accountability." The study authors' overall conclusion is that "scientists believe the public knows little about a range of scientific issues and that they see this knowledge deficit as shaping risk perceptions, policy preferences, and decisions." Scientists "emphasize a need to educate the public so that non-experts will make policy choices in line with the preferences of scientists."

In other words, scientists are in the thrall of what communications scholars consider to be one of the great myths about public communication-the knowledge deficit model. ${ }^{6}$ This is the belief, largely held by scientists, that "ignorance is at the root of social conflict over science.... Once citizens are brought up to speed on the science, they will be more likely to judge scientific issues as scientists do and controversy will go away."

The knowledge deficit model held by scientists dismisses any possibility that the relationship between religion and science, and any possible conflict, is moral. Indeed, it can lead scientists to redefine obvious cases of moral conflict as being about knowledge. For example, Sir Peter Medawar commented on public fears of genetic manipulation in the 1970 s by ignoring the obvious moral conflict between scientists and the public and attributing conflict to a lack of knowledge. He wrote that "I find it difficult to excuse the lack of confidence which otherwise quite sensible people have in the scientific profession ... for their fearfulness, laymen have only themselves to blame and their nightmares are a judgement on them for their deep-seated scientific illiteracy."

\section{Scientists Who Reflect on the Public's Views of Religion and Science}

I lack a survey of the scientists who are engaged in the religion and science debate, so I will instead conduct a small case study of a group of elite scientists engaged in a religion and science event. The assumption by scientific elites that systemic knowledge conflict also organizes the thought of the religious public is quite 
evident in the 2005 Terry Lectures at Yale. That year was the $100^{\text {th }}$ anniversary of the prestigious lectureship devoted to "religion and its application to human welfare in the light of scientific knowledge and philosophical insights."

This makes a good case study because the prominence of the event meant that some of the more influential scientists who had focused on the religion and science debate were invited to speak, and because they were asked their views of the religious public. The fact that it was held under the auspices of the Yale Divinity School suggests that if anything the scientists would be more restrained in what they would otherwise say about religion.

The Yale selection committee decided to ask the question why the controversy between science and religion in the public "continues with such force." ${ }^{10}$ The organizers asked a philosopher of religion, a historian of religion and science, a sociologist of religion and three scientists to each provide an explanation for the continued conflict in the public. What resulted is that all of the lecturers assumed that "controversy" was about knowledge claims, except, as we might expect, the sociologist, who had more knowledge of the contemporary religious public's views. ${ }^{11}$ The scientists in particular reinforced the idea that the public's conflict was about knowledge claims.

Paleontologist Keith Thomson introduced the series of lectures by repeating the systemic knowledge conflict narrative, saying "there is bound to be a debate because science and religion are two very different entities with different ways of arriving at 'truth.' Both have claims on both our reason and our intuition." One disadvantage for religion in this debate is that it is seen as "imposing a body of truths that must be accepted on faith and revelation rather than discovery and analysis." In case this was not clear enough, he then wonders what science's greatest liability is "when it comes to public understanding and acceptance." He concludes that the limit on public acceptance is that science "proceeds by making a changing and progressively more uncommon sense out of common sense . . People distrust a science that gives changing, more refined, answers." ${ }^{12}$ Conflict for Thomson is driven by the powerful knowledge-making apparatus of science.

Another scientist on the panel, Lawrence Krauss, at first sounds like he sees moral conflict as the cause of the "continued debate," when he says that conflict is the result of "fear of the moral implications of science and its perceived challenge to religion." However, he also says that debates about evolution are a "straw man," and "what people are challenging is science itself and the methods by which it investigates the universe." So, he sees the religious public as in systemic knowledge conflict with science. It turns out the link to morality for Krauss is that the loss of epistemic standing of the "God caused nature" perspective leads to thinking that science "is inherently atheistic, and thus immoral." ${ }^{13}$ So, any moral conflict is simply the result of the fact that the supernatural is not allowed as a justification for fact claims. In fairness to Krauss, he was focusing on the intelligent design 
movement, and this is one place where both sides are talking about knowledge, with intelligent design advocates trying to overthrow the scientific pyramid that has methodological naturalism at the top.

The first two scientists appear to see a strong version of the systemic knowledge conflict between the religious public and scientists. The final scientist, Kenneth R. Miller, assumed the weak version of systemic knowledge relationship, probably because he is a Catholic who uses Catholic theology to talk about religion and science. Early in his talk he acknowledged that opponents of Darwin often give moral reasons for their opposition, that "Darwin's great idea is indeed seen as the foundation of everything wrong in society, including lawlessness, abortion, pornography, and the dissolution of marriage." ${ }^{14}$ However, his chapter is not about moral conflict but rather primarily shows that Intelligent Design claims are scientifically false.

He finishes with a section that argues for the standard Catholic account of systemic knowledge compatibility based on a science that assumes methodological naturalism. "Nothing could be worse for people of faith than to defer to the Bible to [sic] as a source of scientific knowledge that contradicted direct, empirical studies of nature" he begins. Saint Augustine "warned of the danger inherent in using the Bible as a book of geology, astronomy, or biology . . to Augustine, the eternal spiritual truth of the Bible would only be weakened by pretending that it was also a book of science." Opposing atheist advocates of the strong version of systemic knowledge conflict, where science requires metaphysical naturalism, he rejects their attempts to claim that "science alone can lead us to truth regarding the purpose of existence." ${ }^{15}$ In sum, Miller does not see conflict between his version of science and his religion, but the relationship he depicts is nonetheless the relationship between two forms of systemic knowledge. As we will see in a few pages, he would fit in well with the theologians in this debate.

\section{Scientific Atheists and Their Allies}

By far the group of scientists engaged in the religion and science debate with the biggest soap box are the scientific atheists. For example, an incredible 21.4 percent of a random sample of Americans claim to have heard of Richard Dawkins, undoubtedly the most influential scientific atheist, whereas only 4.3 percent claim to have heard of evangelical scientist Francis Collins, who we will meet later in this chapter. ${ }^{16}$ In general, the scientific atheists have a greater influence on the public's views of religion and science than any other type of academic.

The systemic knowledge conflict view is evident in their writings. They portray both religion and science-among elites and the public-as iron-clad hierarchically structured systems of belief. On the science side, science requires metaphysical naturalism, and therefore any conflict between religion and science is the 
strong systemic form. That is, if you believe in one scientific knowledge claim that has been institutionalized by the scientific community you must believe in them all, and you certainly cannot believe any knowledge claim that is "non-scientific" such as the existence of God. For the scientific atheists, religion must fit into the scientific pyramid or be declared false, starting with what they take to be a fact claim about the world demonstrable through scientific observation-whether God exists.

Regarding values, scientists are not promoting any, but are simply investigating nature. Religiously derived values appear, but they are driven by what the scientific atheists consider the central knowledge claim-the existence of God. Were this false knowledge claim to be eliminated, then the faulty values of the religious public would also be repaired.

This belief in pure logical coherence and hierarchical justification up to first principles is exemplified by Dawkins' admitted theological ignorance. From the view of religious critics of Dawkins, he needs to know something about what he is criticizing. In my terms, religious people complain that Dawkins does not know anything about the middle of the religious pyramid - what Christians really think about creation, miracles, the human and so on. This critique was most evocatively stated by Terry Eagleton in his review of Dawkins' book The God Delusion:

Imagine someone holding forth on biology whose only knowledge of the subject is the Book of British Birds, and you have a rough idea of what it feels like to read Richard Dawkins on theology. Card-carrying rationalists like Dawkins, who is the nearest thing to a professional atheist we have had since Bertrand Russell, are in one sense the least well-equipped to understand what they castigate, since they don't believe there is anything there to be understood, or at least anything worth understanding. This is why they invariably come up with vulgar caricatures of religious faith that would make a first-year theology student wince. The more they detest religion, the more ill-informed their criticisms of it tend to be. ${ }^{17}$

But, this ignorance is not a problem if religion and science are assumed to be perfectly coherent hierarchical structures of knowledge or belief, where all lower-level beliefs are dependent on the top belief. Indeed, Dawkins has admitted that he has not bothered to learn much theology because it is all irrelevant. In reaction to the critique that he does not know very much theology, Dawkins wrote "Yes, I have, of course, met this point before. It sounds superficially fair. But it presupposes that there is something in Christian theology to be ignorant about. The entire thrust of my position is that Christian theology is a non-subject. It is empty. Vacuous. Devoid of coherence or content. . . The only part of theology that could possibly demand my attention is the part that purports to demonstrate that God does exist. This part of theology I have, indeed, studied with considerable attention. And found it utterly wanting." ${ }^{18}$ 
He has effectively defined religion as a hierarchical logical structure of knowledge with "God exists" at the apex. Knocking out this apex leaves us with the only logical conclusion, that all claims below it on the pyramid are false. Moreover, science and religion are coherent knowledge structures that you have to believe all of, because you agree with the first principles, and since these first principles are incompatible, you cannot believe any components of the opposing structure.

Dawkins and other scientific atheists have often been accused of being fundamentalists, but the reasons offered for the similarity with Protestant fundamentalism are varied. If we focus on what the scientific atheists think structures of knowledge are, Dawkins is like a Protestant fundamentalist pastor. Both believe in iron-clad hierarchical knowledge in science and religion. Fundamentalist elites simply insert a different belief at the top and utterly reject any scientific claim that does not fit with that top belief, such as the age of the Earth. Critically, both Dawkins and his fundamentalist adversaries are teaching the public the idea that any conflict between religion and science concerns the strong version of systemic knowledge.

We can also consider the views of Jerry A. Coyne, who is probably the most influential American scientific atheist. The first page of his book Faith versus Fact reveals the base assumption of what the debate is about when he writes that the book "is about the different ways that science and religion regard faith, ways that make them incompatible for discovering what's true about our universe. My thesis is that religion and science compete in many ways to describe reality-they both make 'existence claims' about what is real-but use different tools to meet this goal." In my terms, he thinks both religion and science are primarily methods for making claims about the natural world. Indeed, he sees that "the truth claims religion makes about the universe turns it into a kind of science, but a science using weak evidence to make strong statements about what is true." "Science and religion, then, are competitors in the business of finding out what is true about our universe."19 A lot of his book consists of arguments that religion is about knowledge generation and not about something like moral values. This seems critical to his argument, because if religion is not about knowledge production, then as a scientist he has no argument against it.

Like Dawkins he spends a lot of time on the fact claim that God does not exist because, without an empirically verifiable deity, the entire logically deductive pyramid of religious belief below it collapses. His assumption is that these beliefs are logically coherent. For example, he says the reason that elite scientists are less likely to be religious is that "science's habit of requiring evidence for belief, combined with its culture of pervasive doubt and questioning, must often carry over to other aspects of one's life-including the possibility of religious faith." I emphasize the word "must" in the quote to focus on the assumption he is making about logical consistency. He further demonstrates his assumption by saying that some 
people can wall off this logic: it is the religious scientists who "happen to be the ones who can compartmentalize two incompatible worldviews in their heads." ${ }^{20}$

What is most striking about Coyne's book is not the fairly standard scientific atheist assumptions about what religion is. Rather, it is that he so deeply assumes systemic knowledge conflict that he apparently does not realize that his book makes the case that the actual conflict between science and religion is over morality. In his final chapter titled "Why Does It Matter," he talks about the harms that come from the public using religion to make claims about the natural world. He starts with an extreme and rare case to stand in for all religion, which is "those sects that reject medical care in favor of prayer and faith healing, and enforce this belief on their children," by which he is primarily referring to Christian Science and Jehovah's Witnesses. ${ }^{21}$ Like the Huffington Post bloggers we met in the first few pages of this book, he also claims that religion leads to denial of climate change by citing the religious claims of conservative politicians and an energy industryfunded evangelical think tank. As we will see in Chapter 6, this claim is just based on the assumption that people who do not believe science in one instance cannot believe it in another. This one extremely rare claim and one empirically false claim are about knowledge conflict.

But, the main reasons he thinks that religion should be gotten rid of is that he does not like its moral agenda. In addition to faith healing and climate science, there are "several other areas where science clashes with faith in the public arena." The first is embryonic stem cell research, which has been limited because of religious beliefs that embryos are equivalent to persons. The second is vaccination against the virus that causes cervical cancer, which is spread by sexual contact. Because "many Christians oppose any sex outside of marriage" they oppose the mandatory vaccinations because they think it will encourage sex outside of marriage. Another harm that springs "from the morality claims of faith, claims that flout both science and reason" is "opposition to assisted dying." Most people think it is "merciful to euthanize our dog or cat if it's suffering terribly" but followers of many religions reject this because humans are "the special creation of God, and uniquely endowed with souls."22

While these religious moral claims are all dependent on facts to the extent that religious morality is dependent on a belief in God, these facts are very far up the pyramid. That Coyne's primary opposition to religion appears to be moral can be seen in the fact that the religious opponents of embryonic stem cell research, sex outside of marriage, and opposition to assisted dying would agree with all of the scientific claims about these phenomena. They would agree with embryologists' claims of how many cells an embryo has and what would happen if you were to let it continue dividing. They would agree with how viruses cause cervical cancer. They would agree with descriptions of how people die and how their dying could be assisted. They would just disagree over what we should do about these things. 
These moral debates in the public sphere would be much more efficient if Coyne would just define the morality of science and directly argue about morality.

There are too many scientific atheists to conduct an analysis of each one. I will conclude this section by examining the historian Ronald Numbers' contribution to the Yale conference described above, in which he compiled the views of religion of famous scientific atheists. Numbers is making a point about intelligent design theory, but I repurpose his compilation to show that the scientific atheists not only assume that religion only concerns knowledge claims, but that disproving one knowledge claim by religion through science invalidates the entire knowledge structure-including belief in God-because each piece of knowledge is logically dependent on each other.

Numbers writes that atheist Daniel Dennett has "portrayed Darwinism as 'a universal solvent, capable of cutting right to the heart of everything in sight' —and particularly effective in dissolving religious beliefs." ${ }^{23}$ This is only possible if all religious beliefs are so utterly dependent upon the fact claim that humans did not evolve from lower life forms, or more generally that events do not happen in the world for random reasons, that removing this one piece of the knowledge pyramid causes its collapse.

Scientific atheists also make it clear that science and religion are only about knowledge by comparing knowledge claims from the two. Co-discoverer of the structure of DNA and Nobel prize winner Francis Crick wrote that "the view of ourselves as 'persons' is just as erroneous as the view that the Sun goes around the Earth. ... In the fullness of time, educated people will believe there is no soul independent of the body, and hence no life after death." Oxford chemist Peter Atkins notes appreciatively that science abrogates to itself "the claim to be the sole route to true, complete, and perfect knowledge." Harvard biologist E. O. Wilson writes that "the final decisive edge enjoyed by scientific naturalism will come from its capacity to explain traditional religion, its chief competition, as a wholly material phenomenon. Theology is not likely to survive as an independent intellectual discipline." The late William Provine, who was a biologist and historian at Cornell, wrote that "modern evolutionary biology tells us loud and clear [that] there are no gods, no purposes, no goal-directed forces of any kind. There is no life after death ... There is no ultimate foundation for ethics, no ultimate meaning to life, and no free will for humans either." ${ }^{24}$

In all of these claims against religion by famous scientists, religion only concerns knowledge about the natural world, and therefore is not only in conflict with scientific knowledge, but is doomed to extinction once it is shown that scientific knowledge is superior. Most critically, religion and science are each logically coherent systems of fact claims reaching up to first principles (reason and observation vs. faith), so you cannot believe in one component of a system without believing in them all. 


\section{Why Scientists Assume Any Relationship Concerns Systemic Knowledge}

To explain why the scientists see religion and science as both systemic knowledge structures, and that these are then in conflict, we must start by reiterating what I wrote at the beginning of this chapter. That is, post-Reformation definitions do portray religion as a set of hierarchically oriented beliefs, so we can see why scientists who are not familiar with the religious public would assume that for ordinary religious people "religion" means hierarchically structured beliefs about knowledge. I think science is a systemic knowledge system, although I will argue that it is also a moral system.

In addition to this general explanation, over the years scholars have pointed out that promoting the idea that they are in knowledge conflict with religion is critical to scientists' self-identity and is a way to gather resources. In a seminal series of articles during the emergence of the field of the sociology of scientific knowledge in the early 1980 s, Thomas Gieryn and colleagues examined the boundary drawing that scientists have historically engaged in against pseudoscience, mechanics and religion. Drawing such boundaries was useful for scientists' professional goals, such as "acquisition of intellectual authority and career opportunities." 25

For example, referring to the efforts of John Tyndall in Victorian England, Gieryn writes that "because religion and mechanics thwarted (in different ways) Tyndall's effort to expand the authority and resources of scientists, he often chose them as 'contrast cases' when constructing ideologies of science for the public." ${ }^{26}$ In a later application of these ideas to American court trials over teaching creationism in the classroom, Gieryn and his colleagues conclude that the relationship between religion and science was used to advance the goals of justifying investments in scientific research and education, and the monopolization of "professional authority over a sphere of knowledge in order to protect collective resources for scientists." 27

Historian Peter Harrison also sees that the emergence of what we would now recognize as science in the nineteenth century was partially accomplished by "drawing sharp boundaries and positing the existence of contrast cases" including "science and religion." "Religion is what science is not: a kind of negative image of science" writes Harrison, and "the conflict myth continues to serve the role for which it was originally fashioned in the late nineteenth century, of establishing and maintaining boundaries of the modern conception 'science." ${ }^{28}$

Scientists then promote the myth of an enduring and timeless knowledge conflict between religion and science, with scientists promoting the idea of Galileo being an early martyr for science at the hands of religion. Galileo never went to jail-to paraphrase the title of a book meant to disabuse scientists and others of the conflict myth-but it is in the interests of scientists to continue to say that he did. ${ }^{29}$ 
In a fascinating analysis of how scientists describe the Galileo affair in textbooks and other texts, communications scholar Thomas Lessl finds that the stories about Galileo "reflect the master narrative of 'warfare between science and religion' that has been such a prominent feature of scientific rhetoric during the past century." In the common scientific narrative, Galileo was not only the first person to use empiricism to make discoveries about nature, but this was at the core of his conflict with the Catholic Church. Lessl cites Stephen Hawking's A Brief History of Time, which states that "Galileo, perhaps more than any other single person, was responsible for the birth of modern science. His renowned conflict with the Catholic Church was central to his philosophy, for Galileo was one of the first to argue that man could hope to understand how the world works, and, moreover, that we could do this by observing the real world." Such statements frustrate historians to no end, because they are not fully true. Galileo was not persecuted for his methods or his rationalistic assumptions, and defended his views as descriptions of the world created by God..$^{30}$

We could go on and on with this, as historians show that the myths of the conflict between religion and science of Galileo, Darwin and many others, often promulgated by scientists, are incredibly persistent. The frustration of historians has reached the point where Jon Roberts calls the idea of a universal knowledge conflict between science and Christianity the "idea that wouldn't die." ${ }^{11}$ The question is why scientists keep repeating these false statements. One reason is that contemporary science finds it useful as a way of saying what makes science distinctive and thus worthy of public investment and trust. Another plausible answer is that the myth is a type of identity-work, a set of myths that define the community of scientists in ways that are useful. For example, if older scientists want to teach new scientists that science is rational and disinterested, then it is useful to have an "other" with which to contrast yourself. In Lessl's words, "the presumed irrationality, credulity, and intellectual self-interest attributed to Galileo's opponents in the Church appear in these folk narratives as inversions of the rationalism, skepticism, and disinterestedness of science. Such dramatic demarcations attach distinctive virtues to the scientific culture and at the same time ratify its claims to institutional autonomy". Moreover, with the Galileo legend "the features of the scientific ethos that set it apart from religion are lionized, grounds for the scientific culture's professional autonomy are given an historical rationalization, and a socialevolutionary vision of science as the triumphant road to the future is dramatically visualized." 32

\section{THEOLOGICAL SCIENCE-RELIGION SYNTHESIZERS}

The second group in the academic religion and science debate to examine are the theologian synthesizers, who, after the scientific atheists, are the most prominent. 
As we would expect, most of these theologians are liberal Protestants and Catholics, and many also have a $\mathrm{PhD}$ in a science field and/or are practicing scientists.

They assume that the relationship between religion and science concerns systemic knowledge, and therefore any conflict is due to the failure to synthesize the fact claims of religion and science into one hierarchically structured logically coherent pyramid. They reject the view that science requires metaphysical naturalism, and take the more mainstream view that science only requires methodological naturalism. That is, science cannot address non-demonstrable claims like the existence of God, but science should address demonstrable claims about the natural world like the age of the Earth. The goal of the synthesizers is then to avoid the weak version of systemic knowledge conflict by making religious knowledge claims consistent with scientific knowledge claims generated through methodological naturalism. For example, they want to interpret their religious tradition to make the Genesis narrative consistent with scientific discoveries about the Big Bang. I will examine the writings of a few of the more influential theological synthesizers to show that in their striving to avoid conflict they deeply presume that the relationship between religion and science concerns systemic knowledge..$^{33}$

Again, I do not want to give the impression that these efforts are wrong. Indeed, you could argue that this task of synthesis is what theology is. Rather, my goal is to point out that this perspective cannot be extrapolated to the public.

\section{Ian Barbour's Four Relationships Between Religion and Science}

To see the most common academic depiction of the relationship between religion and science, we should start with the late Ian Barbour, who was one of the modern progenitors of discussions of the relationship between religion and science. Wikipedia, which is undoubtedly a primary information source for the public, claims that Barbour was "credited with literally creating the contemporary field of science and religion." In the citation nominating him for the Templeton Prize, which he won in 1999, John B. Cobb wrote that "no contemporary has made a more original, deep, and lasting contribution toward the needed integration of scientific and religious knowledge and values than Ian Barbour. With respect to the breadth of topics and fields brought into this integration, Barbour has no equal." ${ }^{34}$

Note that, like many of the other academics discussed in this chapter, he does not explicitly make a distinction between elite arguments and what the public would think. While he and others in this group would probably acknowledge a difference, by not being explicit the reader is left to assume that his claims are true for all religious people.

For Barbour, the relationship between religion and science is resolutely about knowledge. Actually, science is only about knowledge, and religion sometimes has to change its theology due to new knowledge, or scientific knowledge raises ethical 
debates that religion can contribute to. But the reaction by religion is always to the knowledge produced by science, not to any of the social or moral aspects of science. Finally, knowledge is or should be coherent within each of the two systems, which reinforces the systemic knowledge conflict perspective.

The capstone book of Barbour's career is When Science Meets Religion: Enemies, Strangers or Partners, published in 2000, in which he reiterates his typology of possible relationships between religion and science. He says early on that this "typology was developed for fundamental science as a form of knowledge, not for applied science in its impact on society and nature." There are four possible relationships between religion and science: "conflict," "independence," "dialogue," and "integration." That all of these relationships are about knowledge is clear from the second sentence of the book: "Most of the founders of the scientific revolution were devout Christians who held that in their scientific work they were studying the handiwork of the Creator." That is, these early scientists were making fact claims about nature, and they saw these fact claims as logically consistent with their theological belief. The second paragraph emphasizes that what is important is that science is a knowledge producer, and that knowledge challenges religion: "New discoveries in science have challenged many classical religious ideas. In response, some people have defended traditional doctrines, others have abandoned the tradition, and still others have reformulated long-held concepts in the light of science." ${ }^{35}$ Again, this is important activity for the elites, but Barbour does not mention that the public might have a different set of priorities, or that religion may be about more than facts about the natural world.

The book is structured around five of "the most widely debated questions," over which science and religion could have a relationship. These are all about knowledge-and all are knowledge claims by scientists that religion has to react to. First, science has shown that the Big Bang occurred, and religion should discuss what this means. Second, quantum physics has shown inherent uncertainty in the universe, and theology can think about what this means for theological thought-in my terms, what quantum physics means for the entire pyramid of theological belief. Third, Darwinism has shown a number of facts about where humans came from, and theology has developed to consider a more immanent God who creates over a long period of time through evolution. Fourth, scientists have suggested that due to genetics and body chemistry, freedom is an illusion. This calls into question the soul and the mind vs. matter distinction, but some theologians have begun to re-think those ideas in light of the science. Fifth, scientists have shown that nature works through rules, but some theologians have taken to showing that this can be made compatible with God acting in the world in a way that does not violate scientific views. Every one of these questions portrays a science that is producing knowledge, and thus religion must react to that knowledge either by changing the system of religious belief or interpreting the meaning of 
that knowledge for the scientists. The debate is most certainly not about the morals promulgated by scientists.

This framing of the relationship as only concerning knowledge is even more clear when we turn to his four possible relationships, which assume that both science and religion are separate, logically coherent belief structures. The first relationship, "conflict," is narrated through debates between Christian Biblical literalists on the one side and materialist Darwinists on the other, where the debate is about "scientific evidence" for evolution..$^{36}$ So, for Barbour, explicit "conflict" is clearly about knowledge claims about nature.

"Independence" holds that science and religion "refer to differing domains of life or aspects of reality," answering "contrasting questions," that science asks "how things work and deals with objective facts;" while "religion deals with values and ultimate meaning. ${ }^{\prime 37}$ This is akin to what was perhaps even more famously depicted as "non-overlapping magisteria" by Steven J. Gould. ${ }^{8}$ This describes two pyramids that reach to the apex of their respective core beliefs. Independence is violated when religion makes scientific claims, such as when fundamentalists make claims about the age of the Earth, or science makes religious claims, such as when scientists promote naturalistic philosophies.

The "independence" relationship is technically advocating no relationship between religion and science, but conflict could be about systemic knowledge (if religion unjustifiably makes knowledge claims) or about morality (if science unjustifiably makes moral claims). However, when he describes the relationship in more detail and applies it to various scientific debates, the primary concern is religion trespassing into knowledge generation, not science trying to develop a moral program. Moreover, his description of the task of religion is not about morality, but usually about a different way of perceiving reality. ${ }^{39}$

The "dialogue" relationship is not only about knowledge, but really emphasizes that science and religion are separate logically coherent knowledge systems. One component of dialogue is talking about knowledge beyond the limits of the abilities of the conversation partner-the "limit questions" which are "raised by science but not answered within science itself." An example would be "why is there a universe at all?"; answering such a question with religion does not impact the nature of scientific knowledge itself. Another component of dialogue is "a comparison of the methods of the two fields." For example, religious ideas of what cannot be observed, like God, may help scientists develop methods for unobservable subatomic particles. Science can take from religion whatever metaphors and models may be useful for integration into its system of knowledge. Science properly remains a logical unity only beholden to its own epistemology, as in this relationship the two sides are "respecting the integrity of each other's fields." ${ }^{\circ}$

Finally, "integration" is a partnership of religion and science, and this partnership is about knowledge claims, referencing the natural theology tradition that 
sought proof of God in the facts of nature. For example, Stephen Hawking has claimed that "if the rate of expansion one second after the Big Bang had been smaller by even one part in a hundred thousand million million, the universe would have recollapsed before life could have formed." To Barbour, this suggests a force controlling the universe, and God "caused" scientific facts, so the system of scientific beliefs should be modified to accept this religious belief. He also references the "theology of nature" tradition, wherein theological ideas are reformulated to fit with scientific facts, such as the idea of original sin, which needs to be "reformulated in the light of science." ${ }^{41}$

While the point here is to mix knowledge claims between the two institutions, this integration view is even stronger in teaching people that religion and science must be logically unified entities. In the end they remain separate but each has become even more logical by not ignoring the fact claims made by each other.

Barbour actually does not advocate the "independence" relationship, which would block off religion from making any contribution to fact claims about the natural world and block off science from making religion more accurate. Independence "avoids conflict, but at the price of preventing any constructive interaction," he writes. His "own sympathies lie with Dialogue and Integration," and especially integration ${ }^{42}$. In general, Barbour's description of the four possible relationships between religion and science reinforces the idea that everyone holds elite standards of logical coherence of belief, and that to believe in any science is to believe in logically coherent empirical knowledge back to the apex of the knowledge pyramid described in Chapter 1. The possibility of propositional belief conflict is also never considered as it is presumed that beliefs are nestled in hierarchical systems of justification (e.g. systemic knowledge).

\section{Alister McGrath}

The dominance of the portrayal of the relationship between science and religion as conflict between logically coherent systems of belief or knowledge can be seen in the work of other influential synthesizers. For example, the prolific Alister McGrath, who has doctoral degrees in molecular biology and theology, is currently the Andreas Idreos Professor of Science and Religion at Oxford University. This long-time participant in these debates titled a 1999 book simply Science and Religion: An Introduction. "Science and religion" is implicitly the history of elites trying to synthesize the knowledge systems of religion and science. The debate is about how one would know anything about the world-a concept high in each pyramid-and the book delves extensively into the philosophy of science and religion, debates over creation, natural theology as well as issues like whether God acts through the indeterminacies in quantum theory. ${ }^{43}$ It is not acknowledged that this is a history of elite debates, and it is either presumed that this is what the 
religion and science debate "is," or that the public views the debate the same as the elites.

Another book by McGrath is titled The Foundations of Dialogue in Science and Religion. Were this focused on the contemporary American public, the foundations of dialogue might concern embryonic stem cell research and be a dialogue about whether scientists should consider other values besides the relief of suffering in their moral calculations. But, given that the dialogue between science and religion is the (unacknowledged) elite debate between theologians and scientists, the book is purely about systemic knowledge. For example, one chapter asks what the differences are between religion and science in how "information about the world is obtained and its reliability assessed." 44

He does write that attention has been paid to "ethical matters," such as "whether recent scientific developments (such as genetic engineering) raise fundamental religious and moral issues." However, systematic engagement with issues like ethics "rests upon a prior substantial engagement with questions of method-including such issues as the way in which knowledge is gained and confirmed, the manner in which evidence is accumulated and assimilated, and particularly the manner in which the world is represented." 45 That is, ethics first depends upon knowledge, and knowledge is therefore more important.

\section{John Polkinghorne}

Among the most famous of these theologian-scientists is John Polkinghorne, a theoretical physicist who later became a theologian and Anglican priest. Later knighted by the Queen, and a recipient of the Templeton Prize, like other theologian-scientists his goal is to make scientific and religious knowledge compatible and logically consistent. For example, the Bible does not say anything about quantum mechanics, but quantum mechanics can be made consistent with Christian theology. A long quote gives a sense of his concerns:

Quantum theory was the first branch of physics to make it plain that the laws of nature do not always have a tightly predictive character rather, sometimes they can take only probabilistic form. . . . Unpredictability is an epistemological property, for it concerns what we can know about what is going on. How we relate what we know to what is actually the case is a central problem in philosophy, and perhaps the problem in the philosophy of science. ... In the case of quantum theory, this realist strategy has been followed almost universally.... In the case of the intrinsic unpredictabilities of chaos theory, the realist option has been a far less popular move so far. Only a minority of us have made it.... We have done so not only because it accords with a certain scientific instinct but also because we see here the possibility of the metaphysical gain of describing a physical world whose process is not only subtle but also supple, in a way that may offer a glimmer of hope of beginning to be able to accommodate 
our basic human experiences of intentional agency and our religious intuition of God's providential interaction with creation. ${ }^{46}$

This dialogue is not about moral values. Nor is it about propositional belief claims where one fact-claim in the Bible contradicts a fact-claim of science. Rather, this dialogue is about whether entire systems of knowledge built up over the centuries are consistent with the scientific system of knowledge.

\section{Why Theologians See Conflict as about Knowledge and Belief}

I have three basic assertions for why these theologians see conflict as concerning systemic knowledge. The first is seemingly obvious, which is that theology is defined as "a system of religious beliefs or ideas," ${ }^{47}$ so obviously those who are experts in theology will talk of systems of related beliefs or ideas. But, that does not explain the focus on knowledge. Indeed, there is another type of theologian that is not considered to be part of a religion and science debate, who are, to use the Christian terms, moral theologians (Catholic) and Christian Social Ethicists (Protestants). The fact that the second type of theologian is not thought to be engaged in a "religion and science debate," even when they debate ethics with scientists, shows the utter dominance of the knowledge perspective.

A second reason why the synthesizing theologians only see knowledge conflict is because they are focused on dialogue with scientists-and scientists only think of themselves as engaged in discovering knowledge. Indeed, many of the most prominent of these synthesizers started their careers as academic scientists and only later became theologians. Science is clearly the dominant partner in this dialogue, as theology is reacting to scientific developments, not the inverse. Even if theologians were to recognize various moral conflicts between religion and science, they would not be able to get scientists to focus on morality because this is not what scientists think science "does."

The final reason is that theologians do not have any systematic way of getting input from the ordinary members of their religions-theology is not known for using the sociology of religion as a source. I will argue below that the conflict for the religious public is more concerned with morality. The one-way flow from theologian to the pews means that the public's view of religion and science that would contradict the theologians' natural inclination cannot reach its target.

\section{DIALOGUE ASSOCIATIONS}

Associations that try to produce dialogue and understanding between scientists and religious people are very similar to the theological synthesizers. The organizations are largely led by religious scientists. These are probably the most public 
face of the religion and science debate because of their websites and their educational materials produced for a general audience. And, to continue the narrative of this chapter, they portray any relationship between religion and science as about knowledge, not about morals or values.

However, the fact that these associations try to interact with the public allows me to begin to develop my argument about the public's views. Segueing into my analysis of later chapters, I will show that the closer these associations get to interacting with the religious public, and not just the elites, they unreflectively start describing the relationship_and conflict_as moral and not about knowledge. I examine two associations that are arguably the most visible-one because of its founder and topical focus, and the other because of its association with the most prominent scientific organization in the world.

\section{BioLogos}

BioLogos is concerned with integrating scientific claims about biology and evolution with evangelical Protestant belief. Part of its centrality to the debate is the result of its focus on the most prominent disagreement between religion and science. BioLogos began in 2006 when geneticist Francis Collins, then Director of the Human Genome Project, wrote a book about his own faith and the compatibility of evangelical belief with science. ${ }^{48}$ The publicity around the book spurred him to start BioLogos in 2007, which he led until he was appointed Director of the National Institutes of Health in late 2009, which forced him to step down. BioLogos has continued with leadership from well-known evangelicals involved with religion/science issues. ${ }^{49}$

One can only imagine what it is like to be Francis Collins. One of the most influential scientists in the world, at the pinnacle of influence as Director of the Human Genome Project . . . and yet he claims to be a member of a religious tradition that many elite scientists think is opposed to scientific knowledge. The article reporting on his nomination to head the NIH in Science magazine reported that "some are concerned about his outspoken Christian faith," and prominent atheists wrote in the New York Times suggesting that his religion disqualified him from the post. ${ }^{50}$ Given that Collins is a scientist, an elite, and surrounded by scientists, we can see why these knowledge conflict issues are central to his concerns, as they are in his popular book..$^{11}$

This centrality is designed right into BioLogos. Its five "core commitments" include: "We embrace the historical Christian faith, upholding the authority and inspiration of the Bible." This indicates a standard evangelical yet nonfundamentalist orientation toward the Bible, and points high up the knowledge pyramid. The second is "We affirm evolutionary creation, recognizing God as Creator of all life over billions of years." This idea, also called theistic evolution, 
is that evolution occurred as science describes, but was caused by God, or God produced Creation through evolution. Again, this is a belief high in the pyramid. If you hold that science only requires methodological naturalism, this knowledge claim does not conflict with science because it is not demonstrable with science. BioLogos' concern with knowledge is also made clear in the third commitment, which is that "We seek truth, ever learning as we study the natural world and the Bible." This seems a reference to a long-standing evangelical conception of the two books of God: nature and the Bible, both of which are true..$^{22}$

A more extensive eleven-point "What We Believe" section fleshes this out further. The Bible is clarified as the "inspired and authoritative word of God." The two books of God concept is emphasized, in that "God also reveals himself in and through the natural world he created . . . Scripture and nature are complementary and faithful witnesses to their common Author." Consistency of belief with the scientific consensus is re-emphasized in statements such as "we believe that God created the universe, the earth, and all life over billions of years," and "we believe that the diversity and interrelation of all life on earth are best explained by the God-ordained process of evolution with common descent. Thus, evolution is not in opposition to God, but a means by which God providentially achieves his purposes." Science-at least of the methodological naturalist variety-remains a logically coherent system where you need to accept all of the knowledge claims of science. It is just that the religion in which one should believe is an evangelicalism that does not conflict with any of these knowledge claims.

Finally, BioLogos argues that science requires methodological naturalism and not metaphysical naturalism-using the terms "Materialism" and "Scientism" to represent metaphysical naturalism. BioLogos writes "We believe that the methods of science are an important and reliable means to investigate and describe the world God has made. In this, we stand with a long tradition of Christians for whom Christian faith and science are mutually hospitable. Therefore, we reject ideologies such as Materialism and Scientism that claim science is the sole source of knowledge and truth, that science has debunked God and religion, or that the physical world constitutes the whole of reality." ${ }^{33}$ In my terms, BioLogos works to avoid weak systemic knowledge conflict through synthesis and rejects the definition of science that could produce the strong systemic knowledge conflict.

A large portion of their website is devoted to answering questions about evolutionary creationism. These questions are centrally concerned with avoiding conflict between the knowledge claims of scientists and conservative Protestants, or within conservative Protestantism, with nearly none having any referents to value conflict. ${ }^{54}$

One way to describe BioLogos is that it is part of the ongoing struggle between evangelicalism and fundamentalism, with BioLogos trying to teach the conservative Protestant public the evangelical version of knowledge about the natural world. The creation of a systemic knowledge structure that accounts for theology 
and science is part and parcel of the evangelical worldview. And, I am sure that people affiliated with BioLogos recognize moral conflict with science. My point is that by not emphasizing that the evangelical public might not have a systemic knowledge relationship with science-and may be focused on a moral relationship with science-people who encounter BioLogos might be misinformed about how ordinary evangelicals view science.

\section{The American Academy for the Advancement of Science (AAAS)}

Another prominent dialogue association is the "Dialogue on Science, Ethics, and Religion" (DoSER), founded in 1995 by the American Academy for the Advancement of Science (AAAS). ${ }^{55}$ Its prominence stems from its sponsor. AAAS, founded in 1848, is the world's largest general scientific society, including 261 affiliated societies and academies of science, serving 10 million individuals. It publishes Science magazine, which is the largest paid circulation peer reviewed general science journal in the world, with an estimated readership of one million people. AAAS is the embodiment of institutional science in the U.S. ${ }^{6}$

DoSER was established to "facilitate communication between scientific and religious communities." But, communication about what? The statement continues that "DoSER builds on AAAS's long-standing commitment to relate scientific knowledge and technological development to the purposes and concerns of society at large," which suggests this communication is about knowledge claims. However, their overview page describes the dialogue as not about knowledge, saying that "issues of value and ethics are raised by the appearance of technologies not even imagined by earlier generations. Questions of meaning and religion emerge from our deepening understanding of the natural order. Issues of value and meaning are grounded in the disciplines of ethics and religion." This is then an endorsement of what Barbour called an "independence" relationship, and Gould called "nonoverlapping magisteria." The religious citizens can be relieved that the AAAS is not putting its weight behind metaphysical naturalism in order to eliminate religion as the scientific atheists would want. Rather, science requires only methodological naturalism, and religion takes up matters of value. ${ }^{57}$ At first glance, the website suggests that science is about knowledge, religion is about morality, so there can be no moral conflict as long as science does not talk about its morality.

As we dig deeper, we see DoSER describing the relationship between religion and science as the theological synthesizers do, making sure religion does not contradict scientific knowledge claims. Of the two substantive goals of DoSER, the first is to "encourage an appreciation among scientists, religious leaders, and religion scholars of the ethical, religious, and theological implications of scientific discoveries and technological innovations." ${ }^{58}$ This repeats the idea that science produces knowledge, and this knowledge has implications for religious and theological 
beliefs. The second goal is to "improve the level of scientific understanding in religious communities." Note that there is not a matching goal of "improving the level of theological understanding in scientific communities," suggesting the influence of the knowledge deficit model. This is a one-way dialogue: scientific knowledge has implications for religious belief, and if religious leaders can learn the science, the religious system of belief can be modified.

A report of the DoSER "thematic areas" makes the emphasis on synthesizing religious and scientific knowledge more clear. One theme is "Physics \& the Cosmos," and the description of this theme is dominated by discussion of quarks, quasars and quantum mechanics and other physics facts, which "provoke intriguing physical and metaphysical questions." 59 The theme of "Neuroscience, Brain \& Mind," similarly starts with a compendium of fact claims in this area. ${ }^{60}$ Moral challenges, presumably for religion to work on, are included. For example, "many recent advances in neuroscience also highlight ethical questions with both societal and personal consequences" as science invents things to react to, such as whether people should be mandated to take drugs for neurological problems.

As in the other themes, these scientific facts need to be systematized with religious beliefs. DoSER talks of the spiritual ramifications of neuroscience:

such as the relationship between the human brain and mind. Interdisciplinary research in neuroscience, physics, biology, philosophy and even cosmology has sparked interest in the conversation regarding determinism and free will. The premise is that if actions of minute atoms can be measured with such a high degree of certainty, then can larger aspects of the universe which are comprised of these atoms also be determined with a keenly devised prescription? Do these predictions extend to choices we make, our personalities, and our future? Can we assume biology, conditioning, and probabilistic calculations have declared moot our ability to choose? Theologically speaking, do these determined actions affect our ability to choose good from evil? ${ }^{61}$

This points fairly high up the religious belief pyramid to central concepts like free will. So far we see that DoSER sees a relationship of systemic knowledge between science and religion, where religious and scientific knowledge needs to be synthesized, primarily by religion changing its claims to make them consistent with modern science. While mentioning that religion is concerned with morality and meaning, DoSER does not see a relationship between science and religion over morality because religion has been exclusively given that task. Thus, implicitly, science does not promote a particular morality.

\section{DoSER and the Public}

DoSER, unintentionally in my opinion, gets closer to accurately describing a relationship between religion and science among the public that concerns morals 
when it moves away from elite perspectives focused on knowledge and gets input from regular religious citizens and non-elite scientists who have not spent much time pondering this issue. A recent project of DoSER was the "Perceptions" project, intended to break down false perceptions of scientists by the religious and false perceptions of the religious by scientists. ${ }^{62}$ It primarily focused upon evangelicals, and was conducted in partnership with the National Association of Evangelicals and the American Scientific Affiliation. The National Association of Evangelicals is the largest and most influential coalition of evangelical denominations and organizations in the U.S., and the American Scientific Affiliation is, roughly, an association of evangelical scientists.

The project seems to have started with an assumption of conflict over knowledge or beliefs, with one document stating that "while some evangelicals may be skeptical of scientific theories and worry about the impacts science may have on their communities, some scientists feel that evangelical Christianity hinders the growth of scientific literacy and argue that religion should stay out of public discourse." ${ }^{3}$ The project held community-based workshops that brought together local scientists and local religious leaders. While not the general public, these people were a lot closer to being general members of the public than the elites discussed so far in this chapter, in that these local leaders were not experts in this debate.

Encountering a group much closer to the public seemed to necessitate talking about morality. A discussion guide for the local dialogue groups offered three choices for the relationship between religion and science. ${ }^{64}$ First, "Explore shared values and promote understanding," which may include the values of "service, compassion, and perseverance." This is the rare mention of the fact that scientists have values too, and while DoSER wants to highlight agreement, obviously such values could conflict as well. The second is to "Work together to confront common concerns," such as "health, education, poverty, environmental stewardship, and human rights." This too builds on a shared value-the "common concern for the well-being of others" - and also presumes that scientists have values they promote. The third possibility is to "Ensure civility and minimize confrontation" through separation, with the motto being "good fences make good neighbors." It is striking how the premise of this project is that tensions can be lowered by by-passing elite concerns about fact-claims about the world, and focusing upon the shared values of scientists and the religious community.

Geared toward dialogue about issues other than knowledge claims about the natural world, it became clear at these workshops that the moral conflict between science and religion was two-way, wide, and deep. At a meeting between local evangelicals and scientists in Denver, they talked about renewable energy-presumably a topic over which it would be almost impossible to find knowledge conflict, given that there is nothing in the evangelical tradition that would be opposed to any of the science required for solar panels. One pastor said "It was good to reach into the 
world of people who are opposed (and sometimes outright hostile) to my worldview, to understand and remember that each one is a person with very real needs." ${ }^{\prime 5}$

At the Atlanta workshop, again focused on evangelicals and scientists, the report indicated that "other topics-human origins, evolution, stem cell research, and human sexuality-were identified as areas around which it will be more difficult to find agreement." Two or three of these are fact-claims and one or two of these are moral claims-depending on what the discussion of human sexuality was about.

The pastor of a Baptist church near Atlanta said he was "surprised to learn that a lengthy ethical review process governs all publicly funded research. I had assumptions that were not correct. In one instance, we were talking about the sanctity of life. The traditional view among many evangelicals is that scientists really have very little to do with 'sanctity of life' . . But to hear them say, 'No, life is very important', and to understand why they're doing what they're doing was eye-opening."

Clearly, this pastor thinks that scientists have a particular moral stance in public debates about embryonic life, and that "scientist" means "those who do not follow standard moral norms," not "those who discover knowledge." Another participant described another scene from the workshop where a biologist quipped, seemingly to break the tension, that "We have morals, too!" ${ }^{66}$ The biologist's quip suggests a deep assumption on the part of the religious participants that scientists are amoral or immoral people. Debates about knowledge seemed to be quite secondary.

The program director reported in a newsletter of the AAAS what I will show in subsequent chapters: that evangelicals are not rejecting scientific facts because of how these facts were generated, but because they oppose the moral message that comes with these facts. The director wrote:

In fact, a deeper probe shows that it is actually the underlying basic philosophical concerns of religious citizens toward science that can lead to responses of either enthusiastic support for science or else rejection of scientific data in ways that can be sometimes baffling to scientists.

One evangelical leader who advises the project points out that people within his constituency are often more concerned with the "package" that they perceive may be coming along with science, rather than any particular result. For example, it may not be "the fossil record" or the age of the universe that troubles, but rather the perception that "evolutionary science implies godlessness" or the concern that "if my child is taught evolution in school, will it come wrapped in a package of atheism?"

In other words, Conservative Protestants are not opposed to the scientific method per se, but do not like the ideologies that seem to come implicitly wrapped in those scientific claims, such as the metaphysical naturalism of the atheist scientists. When the project leadership encountered the religious public, they saw that conflict was not primarily about knowledge claims, but was about values or morals. 
While this moral conflict was glancingly identified, it was not highlighted, presumably because all of the leaders of the project had knowledge conflict in their minds. When the perceptions project later turned back to the elites who ran it, predictably the conflict reverted to being about knowledge. This is exemplified by the fact that, after the dialogue workshops, DoSER produced a booklet targeted to evangelical congregations called "When God and Science Meet: Surprising Discoveries of Agreement," produced in conjunction with the National Association of Evangelicals. Critically, the majority of the leaders and writers for this project were either elite leaders of religious groups or academics. The advisory team for this booklet included the president of the National Association of Evangelicals, a program officer for DoSER (who is also a scientist who works for NASA), the Dean of Natural and Social Science at Wheaton College (a flagship evangelical institution), the director of the American Scientific Affiliation, and a pastor in the Washington area. They asked a number of people who were both "committed Christians" and "credentialed scholars" to write very short essays. With the concerns of elites returning to the forefront, this booklet is all about systemic knowledge conflict.

The president of the National Association of Evangelicals sets the tone in the introduction by making it clear that this is all about fact claims. "We hear our doctor describe a life-threatening diagnosis in scientific terms and then rush to the hospital chapel, where we pray for divine intervention. We listen to a pastor's sermon from the Bible and wonder how it fits with the latest article in Time or National Geographic. We are dazzled by the discoveries about tiny DNA or massive galaxies and are humbled by the simplicity of the Bible's opening line that 'God created the heavens and the earth (Genesis 1:1)." He offers a solution to knowledge conflict by quoting Saint Augustine: "Let every good and true Christian understand that wherever truth may be found, it belongs to his Master," which is often paraphrased as "All truth is God's truth." ${ }^{67}$

In the rest of the essays there are a few passing references to scientists pushing metaphysics and moral values. There are warnings about "scientists who arrogantly puff up their knowledge of nature into materialistic metaphysics, or who claim that science trumps all non-scientific moral restraint," or of science implicitly teaching naturalism beyond the lab. However, by and large the ten other short essays reiterate a version of the systemic knowledge conflict narrative. For example, the two books of God perspective is ubiquitous, such as where the booklet claims that scientific skills "provide real knowledge of God's real world, not to be overruled by theological or church authority." ${ }^{6}$

In sum, when DoSER is focused on elites, it reinforces and reflects the elite view of a systemic knowledge conflict. However, when it encounters the public, in this case by facilitating conversations between local pastors and scientists, it turns out that moral conflict is just as important as knowledge conflict. 


\section{THE TEMPLETON FOUNDATIONS}

Readers who are familiar with these debates will note that nearly every person and organization discussed in the synthesizer and dialogue sections of this chapter-and numerous people who would fit in those categories but who were not mentioned-are involved with the Templeton foundations in some way. There are three foundations: The John Templeton Foundation, the Templeton World Charity Foundation, and the Templeton Religion Trust.

Sir John M. Templeton (1912-2008) was an early innovator in the mutual fund industry, making a large fortune along the way. His upbringing was in both the Cumberland Presbyterian Church (generally an evangelical Protestant denomination) and, seemingly paradoxically, the Unity Church. ${ }^{69}$ The Unity School of Christianity (Unity Church) was founded by Charles and Myrtle Fillmore in 1889, and is a metaphysical and mystical blend of Christianity and pantheism. This group emphasizes that the mind controls healing, that God is an impersonal principle, that God is in everything, that the divine exists within everyone, there is no Heaven or Hell, and that Jesus was an exemplar of spiritual truth, not the Christ. ${ }^{70}$

Templeton had a very strong view of the abilities of science, seeing that it was primarily through scientific research that religion could make "spiritual progress." It is quite clear from his voluminous writings that in his life he was primarily concerned with discovering the truth of reality. While clearly science was to be used to discover truth about nature, Templeton was clear that there was much reality beyond nature. Such truth was not to be found through at least present-day science or through religion, but through a religion that used science to discover more truths. Scientific research would "supplement the wonderful ancient scriptures" that were limited by their time. ${ }^{11}$ Thus, both science and religion are about true knowledge.

He was obviously not an advocate of a science that required metaphysical naturalism, given that he thought science could be used to show the details of what God truly is. He was an advocate of a science that requires methodological naturalism-God is not part of a scientific explanation, but scientific findings can help us understand God. That is, he was the ultimate advocate of synthesis, where science would proceed using a secular method, and religion would learn from that science, adjusting its doctrines as it approached spiritual truth.

This is clear in his long-time advocacy of a "humble approach in theology and science." The problem was that while scientists were humble, the theologians were not. He wrote that "as part of a historical legacy of the scientific method, most scientists have learned to avoid the stagnation that comes from accepting a fixed perspective. ... They have learned to become epistemologically open-minded, always seeking to discover new insights and new perspectives." However, "often theologians, religious leaders, and lay people can be blind to obstacles they themselves 
erect. . . Many do not imagine that progress in religion may be possible, perhaps by appreciating ways that sciences have learned to flourish and by being creatively open to a discovery-seeking and future-oriented perspective. For so many religious people, the future of religions seems nothing much beyond the preservation of ancient traditions." ${ }^{72}$

He clearly envisioned scientific research in fundamental physics, such as quantum mechanics, as providing spiritual insight into the "mind of God." Another approach to spiritual progress was to use science to determine whether there was evidence of "universal purposes in the cosmos." Other fields like human evolution could tell us about the spiritual practices of Neanderthals, which could give us spiritual insight today. Another Templeton program examined "conceptually expansive ways of understanding the world," as a way to "connect science with concepts of divinity," and included research in "quantum information theory, quantum chaos, game theory and ethics, emergence of order, timetabling, consilience, the nature of mathematics, the limits of knowledge, aesthetics, the theology of artificial intelligence, and the theology of extraterrestrials." 73 Templeton, and his foundations, were also strong advocates of the idea of dialogue between religion and science.

To return to my terminology, Templeton was, like the theological synthesizers, an advocate of the weak version of the systemic knowledge relationship between religion and science. Religion and science were in conflict over fact claims, but his hope was to avoid conflict by synthesizing the two pyramids into one coherent one that would actually be an improvement on both. Critically, science and religion are not centrally concerned with morality, but rather, and ideally, both are concerned with determining spiritual truth.

Templeton and his foundations did not create the synthesizers and the dialogue promoters - those were part of academia long before Templeton came on the scene. And, again, this sort of research is totally legitimate and is, in fact, what theologians are supposed to be doing. What Templeton and his foundations did was to amplify these ideas, involve more people than would otherwise be involved, and make these ideas much more publicly prominent than they otherwise would be. Like the other debaters in this and the following chapter, it would have been better for public debate about religion and science if Templeton grantees had been required to emphasize in all of their output that what is being discussed may not be how the general public views religion and science. Moreover, an implication of the later pages of this book is that the Templeton foundations might consider whether moral conflict is stopping many religious people from accepting the science that Templeton thought was required for spiritual progress.

\section{CONCLUSION}

The overwhelming assumption among scientists and theologians in the academic religion and science debate, as well as the dialogue associations, is that there is a 
systemic knowledge relationship between religion and science. This is almost a statement of faith among scientists who think that since they are only producing knowledge, the only reason anyone else would be in conflict with them would, of course, be about knowledge. This reaches its apotheosis in the form of the scientific atheists who are assuming a different scientific belief system than most other scientists-a metaphysical naturalism instead of just a methodological naturalism—which makes holding any religious idea at all incompatible with science.

Fundamentalist Protestant Biblical inerrantists ironically agree with the scientific atheists about knowledge conflict, but simply reverse the conclusion: it is scientific knowledge that needs to be modified because it is incompatible with fundamentalist Biblical exegesis. The theological synthesizers also see any relationship as concerning systemic knowledge, but to avoid conflict they aim to change the religious knowledge system so that knowledge conflict does not exist. This perspective has been amplified by funding from the Templeton foundations. Critically, all of those discussed in this chapter are implicitly teaching systemic knowledge conflict to the public. 